\title{
A high-throughput segregation analysis identifies the sex chromosomes of
}

\section{Cannabis sativa}

Djivan Prentout ${ }^{1}$, Olga Razumova ${ }^{2,3}$, Bénédicte Rhoné ${ }^{1,4}$, Hélène Badouin ${ }^{1}$, Hélène Henri ${ }^{1}$, Cong Feng ${ }^{5,6}$, Jos Käfer ${ }^{1}$, Gennady Karlov², Gabriel AB Marais, ${ }^{1, *}$

1. Laboratoire de Biométrie et Biologie Évolutive UMR 5558, Université Lyon 1, CNRS, F69622 Villeurbanne, France

2. Laboratory of Applied Genomics and Crop Breeding, All-Russia Research Institute of Agricultural Biotechnology, Timiryazevskaya Str. 42, Moscow 127550, Russia

3. N. V. Tsitsin Main Botanical Garden of Russian Academy of Sciences, Botanicheskaya Str. 4, Moscow 127276, Russia

4. Institut de Recherche pour le Développement, UMR DIADE, IRD, Université de Montpellier, F-34394 Montpellier, France

5. Chongqing Medical University, No. 1 Yixueyuan Road, Yuzhong District, Chongqing, 400016, China;

6. BGI-Shenzhen, Beishan Industrial Zone, Yantian District, Shenzhen 518083, China;

*corresponding author: Gabriel Marais; LBBE - UMR 5558, CNRS / Université Lyon 1, campus de la doua, 69622 Villeurbanne cedex, France; gabriel.marais@univ-lyon.fr 
bioRxiv preprint doi: https://doi.org/10.1101/721324; this version posted July 31, 2019. The copyright holder for this preprint (which was not certified by peer review) is the author/funder, who has granted bioRxiv a license to display the preprint in perpetuity. It is made $\underline{\text { RESEARCH }}$ available under aCC-BY-NC-ND 4.0 International license.

Running title: sex chromosomes of Cannabis sativa

Key words: Cannabis sativa, sex chromosomes, THC, sex-linked genes, sex-biased genes

\begin{abstract}
Cannabis sativa-derived tetrahydrocannabinol (THC) production is increasing very fast worldwide. $C$. sativa is a dioecious plant with XY chromosomes, and only females (XX) are useful for THC production. The $C$. sativa sex chromosomes sequence would improve early sexing and better management of this crop; however, the $C$. sativa genome projects failed to identify the sex chromosomes so far. Moreover, dioecy in the Cannabaceae family is ancestral, $C$. sativa sex chromosomes are potentially old and thus very interesting to study as little is known about the last steps of sex chromosome evolution in plants. Here we RNA-sequenced a $C$. sativa family (2 parents and 10 male and female offspring) and performed a segregation analysis for all $C$. sativa genes using the probabilistic method SEX-DETector. We identified >500 sex-linked genes. Mapping of these sex-linked genes to a $C$. sativa genome assembly identified a single chromosome pair with a large non-recombining region. Further analysis of the $>500$ sex-linked genes revealed that $C$. sativa has a strongly degenerated $\mathrm{Y}$ chromosome and represents the oldest plant sex chromosome system documented so far. Our study revealed that old plant sex chromosomes can have large non-recombining regions and be very differentiated and still be of similar size (homomorphic).
\end{abstract}




\section{INTRODUCTION}

Cannabis sativa is an ancient crop (Schultes et al. 1974) with two main traditional uses: marijuana and hemp (Small 2015). Marijuana, which is used in folk medicine, as a recreational drug, and lately in conventional medicine (Alexander 2016), has a narcotic effect thanks to tetrahydrocannabinol (THC) and other cannabinoids produced in high concentration by some $C$. sativa cultivars. Until recently, the use of marijuana was prohibited in almost all countries, but $C$. sativa-derived products with high THC concentrations are now legal in several US states, Australia, Germany, Peru and the UK for medicinal purposes (Offord 2018) and also in Uruguay, Canada and several US states for recreational use (Yeager 2018). In the US, marijuana legal economy amounted $\sim \$ 17$ billion in 2016 and may reach as much as $\$ 70$ billion / year by 2021 (McVey 2017). However, legalisation of marijuana is so recent that very few biotech tools have been developed for high THC-producing C. sativa cultivars (Yeager 2018). Interest on hemp is also increasingly attractive as crop for the sustainable production of fibres and oils (Andre et al. 2016; Salentijn et al. 2019). Hemp cultivars usually have a low level of THC and can legally grow in many countries where marijuana is illegal. Features of male and female hemp plants differ and early sexing is also wanted.

THC reaches the highest concentrations in female inflorescences (bracts), so that only female C. sativa plants are of economical importance; furthermore, pollinated female plants produce smaller inflorescences and therefore less THC (Small 2015). It is thus important to avoid growing male plants as they are a waste of resources, labour and space. Sexual dimorphism in C. sativa is weak as in many dioecious plants (Barrett and Hough 2013), and sex can be determined with certainty only when the plants start flowering (Small 2015). C. sativa is a dioecious plant in which sex is determined by a XY chromosome system (Divashuk et al. 
bioRxiv preprint doi: https://doi.org/10.1101/721324; this version posted July 31, 2019. The copyright holder for this preprint (which was not certified by peer review) is the author/funder, who has granted bioRxiv a license to display the preprint in perpetuity. It is made $\underline{\text { RESEARCH }}$ available under aCC-BY-NC-ND 4.0 International license.

2014). Indeed, a few Y-linked genetic markers have been identified in the past and are used to sex C. sativa seedlings (e.g (Techen et al. 2010)). However, it is not known whether these markers work with all cultivars. The $C$. sativa sex chromosomes sequences would thus be an important genomic resource that could help improving agricultural yields. However, the $C$. sativa genome projects (van Bakel et al. 2011; Grassa et al. 2018; Laverty et al. 2019) have failed to identify the sex chromosomes, despite chromosome-level assemblies in the latest projects.

C. sativa is one of 15,600 dioecious species of flowering plants (Renner 2014). Dioecy and sex chromosomes have evolved multiple times in plants (Renner 2014) but very few plant systems have been studied in details (Ming et al. 2011; Charlesworth 2015; Muyle et al. 2017) and the current model for the evolution of plant sex chromosomes includes many gaps, the late stages in particular have not been studied. Old animal sex chromosomes systems are usually heteromorphic with the Y being smaller than the X (Charlesworth et al. 2005; Bachtrog 2013). Heteromorphic systems in plants are much more recent and in the case of Silene latifolia and Coccinia grandis, the Y is larger than the X (Matsunaga et al. 1994; Sousa et al. 2013), probably due to accumulation of DNA repeats on the Y (Sousa et al. 2016; Hobza et al. 2017). The Cannabaceae and related families (Urticaceae, Moraceae) family is expected to derive from a dioecious common ancestor (Zhang et al. 2019). The sex chromosomes of $C$. sativa could thus be much older than those of the species studied so far. Interestingly, $C$. sativa $\mathrm{X}$ and $\mathrm{Y}$ chromosomes are of similar size (= homomorphic, see (Divashuk et al. 2014)). Here we used a recently developed statistical tool to identify X-and Y-linked genes, called SEX-DETector (Muyle et al. 2016). SEX-DETector analyses genotyping data from a cross (2 parents and a few offspring individuals, see Figure 1). Patterns of allele transmission from parents to progeny differ for an autosomal or a sex-linked gene. For example, an allele only transmitted from father to sons is clearly indicative of a Y-linked allele. SEX-DETEctor relies 
bioRxiv preprint doi: https://doi org/101101/721324; this version posted July 31 2019. The copyright holder for this preprint (which was not certified by peer review) is the author/funder, who has granted bioRxiv a license to display the preprint in perpetuity. It is made $\underline{\text { RESEARCH }}$ available under aCC-BY-NC-ND 4.0 International license.

on a probabilistic model that accounts for typical errors in genotyping data and is used to compute, for each gene, the probability of autosomal and sex-linked segregation types. This key feature of SEX-DETEctor makes it better at making inferences about segregation type than an empirical approach relying on data filtering to remove genotyping errors would do (better sensitivity, similar specificity, see (Muyle et al. 2016)). We applied SEX-DETector to C. sativa, inferred sex-linked genes and used those genes to 1) identify the sex chromosomes of $C$. sativa in an available reference genome assembly 2) characterize the $C$. sativa $\mathrm{XY}$ system and compare it to other plant systems.

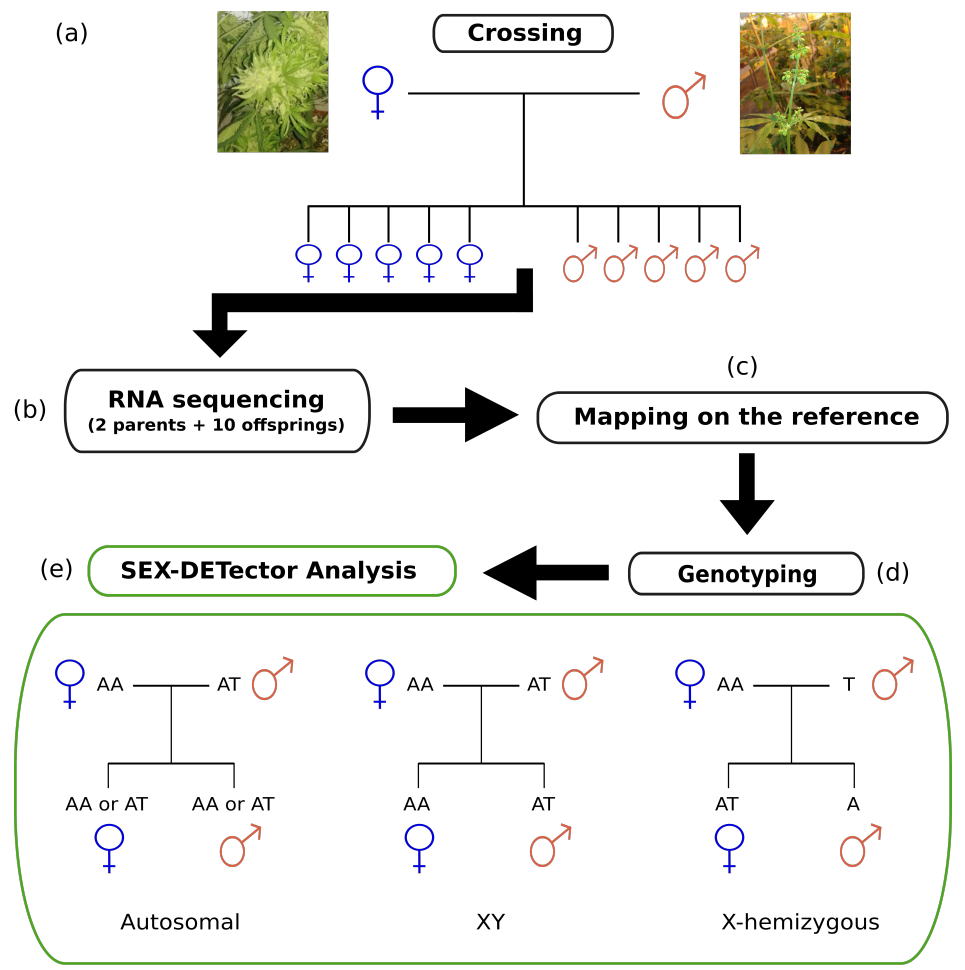

Figure 1: Experimental design and bioinformatic pipeline to identify sex-linked genes. The SEX-DETector analysis relies on obtaining genotyping data from a cross (parents $+\mathrm{F} 1$ progeny). It infers the segregation type based on how alleles are transmitted from parents to offspring. Examples of segregation patterns are shown here for the three segregation types included in SEX-DETector. See Methods for more information.

\section{RESULTS}

\section{Identifying sex-linked genes in $C$. sativa}

More than 576 millions 50 bp single-end reads of the parents and 5 male and 5 female offspring were mapped on the reference transcriptome of (van Bakel et al. 2011), and all 
bioRxiv preprint doi: https://doi org/101101/721324 this version posted July 31,2019. The copyright holder for this preprint (which was not certified by peer review) is the author/funder, who has granted bioRxiv a license to display the preprint in perpetuity. It is made

\section{$\underline{\text { RESEARCH }}$} available under aCC-BY-NC-ND 4.0 International license.

individuals were genotyped (see Methods). Of these, 11.515 were inferred as autosomal, and 565 genes were identified as sex-linked. The latter included $347 \mathrm{X} / \mathrm{Y}$ gene pairs and $218 \mathrm{X}$ hemizygous genes (i.e. genes lacking Y copies, see Methods and Table 1). The sex-linked genes represented $4.6 \%$ of the genes for which SEX-DETector produced an assignment.

Table 1: Results of the SEX-Detector analysis

\begin{tabular}{|l|c|}
\hline & Numbers \\
\hline All genes* & 30,074 \\
\hline $\begin{array}{l}\text { Genes with at least 1 SNP detected, used for SEX-DETector } \\
\text { analysis }\end{array}$ & 28,456 \\
\hline Genes with undetermined segregation type** & 16,381 \\
\hline Autosomal genes & 11,510 \\
\hline All sex-linked genes & 365 \\
\hline X/Y gene pairs & 218 \\
\hline X-hemizygous genes & $70 \%$ \\
\hline Estimated Y gene loss rate & \\
\hline
\end{tabular}

* transcripts from the gene annotation of the reference genome, see Methods ** lack of information

\section{Identifying the sex chromosome pair in $C$. sativa}

A total of 363 sex-linked genes (out of the 555 that we could map) mapped to the chromosome 1 in the reference genome (XY gene pairs: 166/340 $=48.8 \%$, X-hemizygous genes: $197 / 215=91.6 \%$, Figure 2), which points to chromosome pair number 1 being the sex chromosome pair. 192 sex-linked genes (i.e 36\% of all sex-linked genes) mapped to other chromosomes (discussed below). Sex chromosomes typically have non-recombining regions 
bioRxiv preprint doi: https://doi.org/101101/721324; this version posted July 31, 2019. The copyright holder for this preprint (which was not certified by peer review) is the author/funder, who has granted bioRxiv a license to display the preprint in perpetuity. It is made

\section{$\underline{\text { RESEARCH }}$} available under aCC-BY-NC-ND 4.0 International license.

in which the synonymous divergence between the $\mathrm{X}$ and $\mathrm{Y}$ copies of a sex-linked gene (also called gametologs) can be substantial (Charlesworth 2015; Muyle et al. 2017).

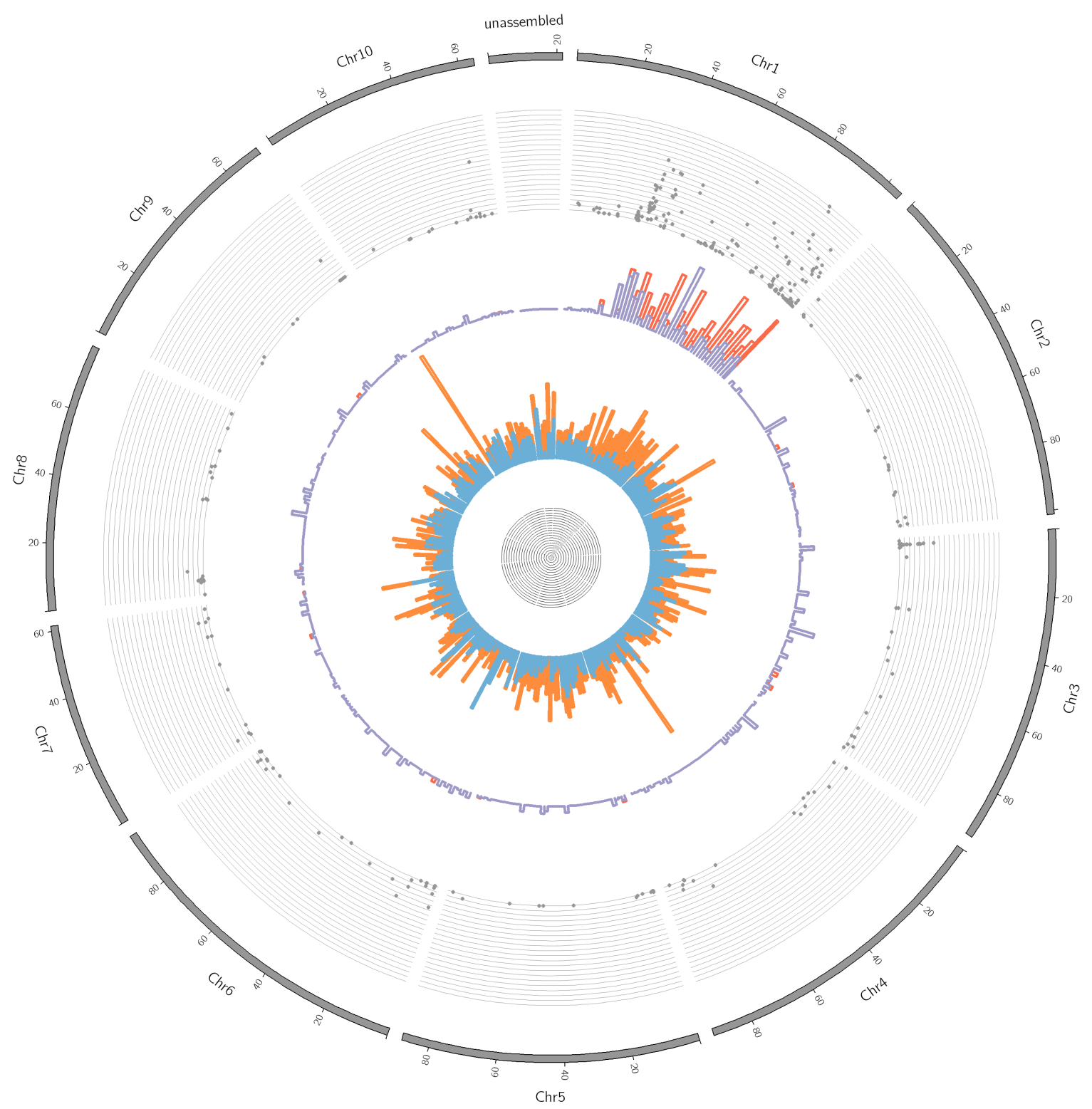

Figure 2: Distribution of the sex-linked and sex-biased genes onto the $C$. sativa reference genome. From outer to inner rings: 1) chromosomes from 1 to 10 and unassembled scaffolds of the reference genome (Grassa et al. 2018), 2) X-Y dS values (from 0 to 0.4 ), 3) cumulative distribution of the XY-linked genes (in blue) and X-hemizygous genes (in red) corrected for gene density (proportion of sex-linked genes among all genes)), 4) distribution of genes with sex-biased expression: male-biased (light blue), female-biased (orange) (proportion of sexbiased genes among all genes).

Using the sex-linked SNPs inferred by SEX-DETector, we are able to quantify the synonymous divergence (dS) between $\mathrm{X}$ and Y copies, which reaches 0.4 in the mostly 
bioRxiv preprint doi: https://doi.org/101101/721324; this version posted July 31,2019. The copyright holder for this preprint (which was not certified by peer review) is the author/funder, who has granted bioRxiv a license to display the preprint in perpetuity. It is made

\section{RESEARCH} available under aCC-BY-NC-ND 4.0 International license.

divergent XY gene pairs (Figure 3A). We found that the most divergent XY gene pairs (showing the highest $\mathrm{X}-\mathrm{Y}$ dS values) mapped to the chromosome 1 as expected if this chromosome pair is the sex chromosome pair. We also found that two regions of the chromosome 1 could be distinguished (Figure 2): region 1 (from 30 to $105 \mathrm{Mb}$ ) where the $\mathrm{XY}$ gene pairs with the highest $\mathrm{dS}$ values are found (mean $\mathrm{X}-\mathrm{Y} \mathrm{dS}=0.079$, top 5\% X-Y dS $=$ 0.32 , top $10 \% \mathrm{X}-\mathrm{Y} \mathrm{dS}=0.28$ ), and where $58.6 \%$ of the sex-linked genes of the region are $\mathrm{X}$ hemizygous (i.e having potentially lost their Y copies), and region 2 (from 1 to $30 \mathrm{Mb}$ ) showing little divergence (mean X-Y dS $=0.014$, top 5\% X-Y dS $=0.05$, top $10 \% \mathrm{X}-\mathrm{Y} \mathrm{dS}=$ 0.04 ) and $9.3 \%$ are $\mathrm{X}$-hemizygous genes. These observations suggest region 1 is the $\mathrm{X}$ specific region (not recombining in males), and region 2 the pseudo-autosomal (still recombining in males) one.

\section{Age of the $C$. sativa sex chromosome system}

We then used the 565 sex-linked genes to study the evolution of sex chromosomes in $C$. sativa. First, we used the dS values of the $\mathrm{X} / \mathrm{Y}$ gametologs and different molecular clock estimates for plants to infer the age of the sex chromosomes on C. sativa (see Methods). Using the maximum observed dS value (0.4), we estimated that recombination suppression between $\mathrm{X}$ and $\mathrm{Y}$ chromosomes have initiated 26.7-28.6 My ago in C. sativa. If we use the dS values of the $5 \%$ or $10 \%$ most divergent gene pairs to be more conservative when estimating the maximum X-Y divergence, we obtain more recent ages for the initial recombination suppression (17.3-18.6 My old using top 5\% X-Y; 12-13 My old using top 10\% X-Y, see Table 2). 
bioRxiv preprint doi: https://doi org/101101/721324; this version posted July 31 2019. The copyright holder for this preprint (which was not certified by peer review) is the author/funder, who has granted bioRxiv a license to display the preprint in perpetuity. It is made $\underline{\text { RESEARCH }}$ available under aCC-BY-NC-ND 4.0 International license.

Table 2: Estimates of the age of the $C$. sativa sex chromosome system

\begin{tabular}{|l|c|c|}
\hline & $\begin{array}{c}\text { Age estimate using all X/Y } \\
\text { gene pairs* }\end{array}$ & $\begin{array}{c}\text { Age estimate using X/Y gene } \\
\text { pairs on chromosome }{ }^{*}\end{array}$ \\
\hline Maximum X-Y dS value & $26.7-28.6$ & $18.7-20$ \\
\hline Top 5\% X-Y dS value & $17.3-18.6$ & $17.3-18.6$ \\
\hline Top 10\% X-Y dS value & $12-13$ & \\
\hline
\end{tabular}

* Estimates obtained using two different molecular clocks (see Methods)

\section{Degeneration of the $Y$ chromosome and dosage compensation in $C$. sativa}

Second, we studied the extent of Y degeneration in C. sativa and estimated gene loss using the $\mathrm{X}$-hemizygous genes (see Methods). This measure of $\mathrm{Y}$ gene loss is of course a rough estimate as it reflects both true loss and simply the absence of expression of the Y copy in flower buds (Bergero and Charlesworth 2011). The number of X-hemizygous genes is known to be underestimated with respect to that of XY gene pairs, as X-hemizygous genes can only be detected when there is polymorphism in the X. To correct for this, we compared the number of X-hemizygous genes (218) and the XY gene pairs with polymorphism in the $\mathrm{X}$ copy (89), and we found that $\sim 70 \%$ of the Y-linked genes may have been lost in C. sativa. The results were similar when focusing on sex-linked genes found on chromosome 1 only $(72.5 \%)$.

To study further Y degeneration, we focused on the expression of the sex-linked genes. Allele-specific expression analysis at the $\mathrm{X} / \mathrm{Y}$ gene pairs revealed a median $\mathrm{Y} / \mathrm{X}$ expression ratio of 0.50 overall ( 347 genes) and 0.47 for chromosome 1 genes only (166 genes, see 
bioRxiv preprint doi: https://doi.org/10.1101/721324; this version posted July 31, 2019. The copyright holder for this preprint (which was not certified by peer review) is the author/funder, who has granted bioRxiv a license to display the preprint in perpetuity. It is made $\underline{\text { RESEARCH }}$ available under aCC-BY-NC-ND 4.0 International license.

Figure 3B), much lower than the expected 1.0 value in case of equal $\mathrm{Y} / \mathrm{X}$ expression (i.e no $\mathrm{Y}$ degeneration). We found some evidence for dosage compensation as, in males, expression of $\mathrm{X}$ was increased when expression of $\mathrm{Y}$ was reduced (Figure 3C). The results were unchanged when using all inferred sex-linked genes or only those found on chromosome 1 (Figure 3 and S3).

A

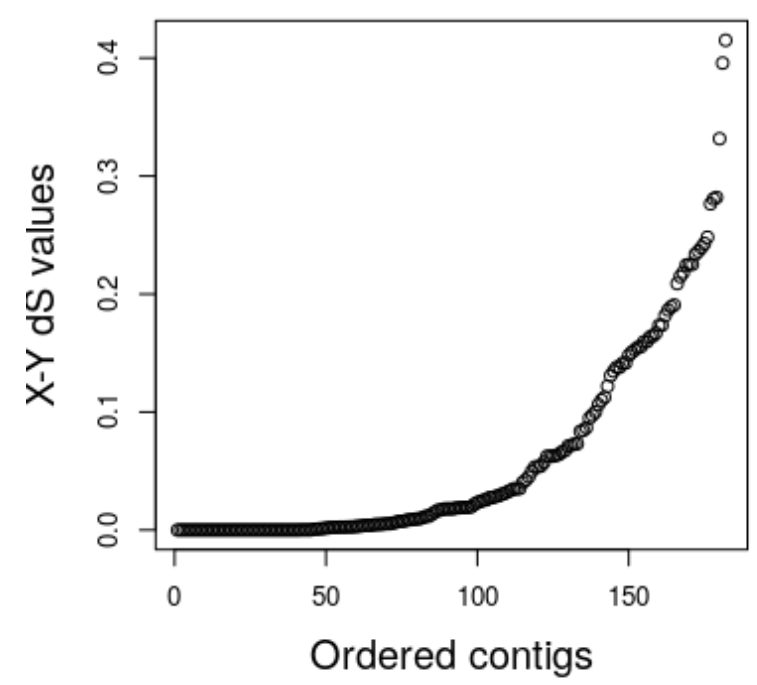

Ordered contigs
B

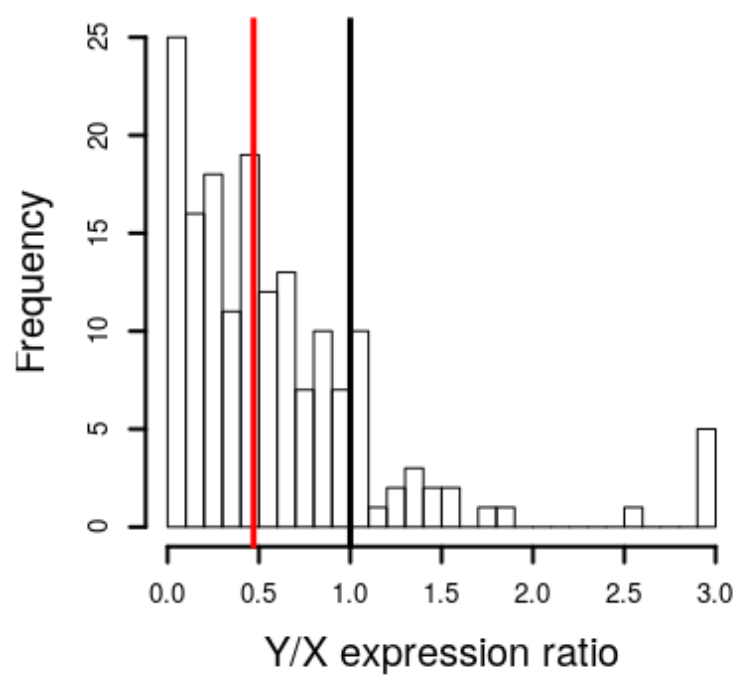

C

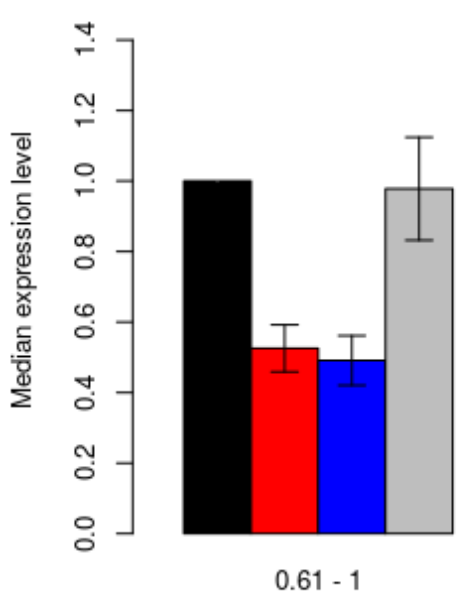

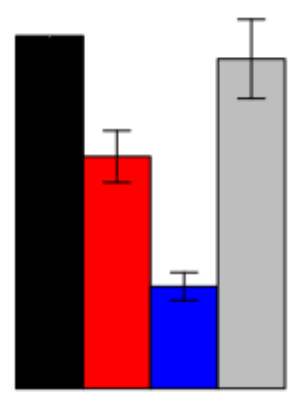

$0.28-0.61$

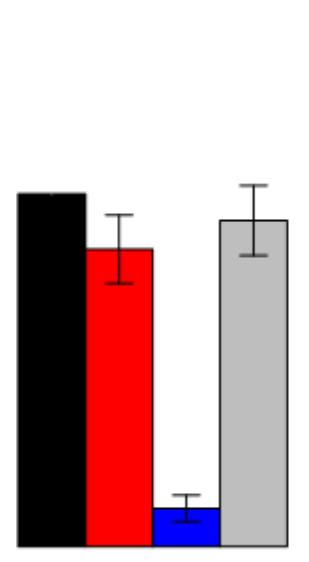

$0-0.28$
- Female $X+X$ expression

- Male X expression

- Male $Y$ expression

- Male $\mathrm{X}+\mathrm{Y}$ expression

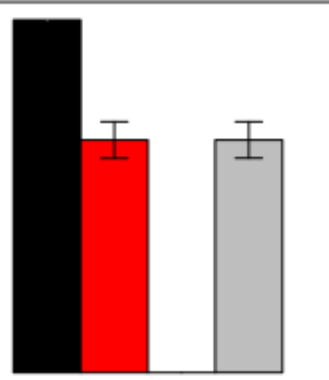

X-hemizygous

$\mathrm{Y}$ degeneration ( $\mathrm{Y} / \mathrm{X}$ expression ratio)

Figure 3: patterns of molecular evolution of $C$. sativa sex chromosomes. A) X-Y dS values for the XY gene pairs, B) Y/X expression ratio for the XY gene pairs, the black bar shows the expected value for no $\mathrm{Y}$ degeneration, the red bar shows the median observed here (median $=$ 0.47). Both are significantly different (Wilcoxon paired test $p$-value $=2.2 \times 10^{-16}$ ). C) Dosage compensation in C. sativa. The expression levels of the $\mathrm{X}$ and $\mathrm{Y}$ alleles in males and females 


\section{$\underline{\text { RESEARCH }}$} available under aCC-BY-NC-ND 4.0 International license.

are shown for gene categories (from left to right, categories 0.61-1 and 0.28-0.61: $\mathrm{N}=44$, category 0-0.28: $\mathrm{N}=43$, X-hemizygous: $\mathrm{N}=218$ ) with different levels of $\mathrm{Y}$ degeneration (measured by the $\mathrm{Y} / \mathrm{X}$ expression ratio). Sex-biased genes (with strong and significant differences in male and female expression) have been removed, as they are not expected to exhibit dosage compensation (see (Muyle et al. 2012; Muyle et al. 2018)). Only sex-linked genes mapping to chromosome 1 have been included here. Figure S1 shows the same analyses with all sex-linked genes.

\section{Genomic distribution of the sex-biased genes in $C$. sativa}

$15.7 \%$ of the genes expressed in flower buds are differentially expressed between male and female individuals (sex-biased genes, see Table 3 and Figure S2). The male-biased genes are significantly more numerous than the female-biased genes $(9.06 \%$ vs. $6.64 \%$, Fisher exact test p-value $=2.2 \times 10^{-16}$, see Table 3), and sex-biased genes are distributed all over the $C$. sativa genome (see Figure 2). The sex-linked genes were significantly enriched among the sexbiased genes $(25.8 \%)$ compared with the autosomal genes $(13.9 \%$; Fisher exact test $\mathrm{p}$-value $=$ $\left.3.7 \times 10^{-13}\right)$

Table 3: List of sex-biased genes.

\begin{tabular}{|l|c|c|c|c|}
\hline Gene categories & Total & $\begin{array}{c}\text { Female-biased } \\
\text { expression }\end{array}$ & $\begin{array}{c}\text { Male-biased } \\
\text { expression }\end{array}$ & p-value* \\
\hline $\begin{array}{l}\text { All genes with sex } \\
\text { biased-expression }\end{array}$ & 3483 & 1473 & 2010 & $2.2 \times 10^{-16}$ \\
\hline Autosomal genes & 1599 & 725 & 874 & $2.1 \times 10^{-4}$ \\
\hline Sex-linked genes & 146 & 79 & 67 & 0.36 \\
\hline XY gene pairs & 87 & 34 & 53 & $6.5 \times 10^{-05}$ \\
\hline X-hemizygous genes & 59 & 45 & 14 & 053 \\
\hline
\end{tabular}

* Exact binomial test, with a theoretical mean equal to 0.5 


\section{$\underline{\text { RESEARCH }}$}

\section{DISCUSSION}

\section{Chromosome pair 1 is the sex chromosome pair in $C$. sativa}

Using SEX-DETector, we have been able to identify a large number of sex-linked genes with a moderate sequencing effort (576 millions of single-end $50 \mathrm{bp}$ reads). We identified a chromosome pair (chromosome 1 in the assembly of (Grassa et al. 2018)) as the sex chromosomes of $C$. sativa. A part of the sex-linked genes did not map to the chromosome 1 , they could be false positives or result from assembly errors (see Text S1).

\section{The sex chromosomes are the largest in the $C$. sativa genome}

This pair is the largest pair of the $C$. sativa genome, in agreement with cytogenetic data (Divashuk et al. 2014). This is frequent in plants with heteromorphic sex chromosomes (X and Y have different size, e.g. S. latifolia, C. grandis, see (Muyle et al. 2017) for review), but also in species with homomorphic chromosomes ( $\mathrm{X}$ and $\mathrm{Y}$ have similar size) such as papaya, where both the $\mathrm{X}$ and $\mathrm{Y}$ increased in size due to the accumulation of repeats (Gschwend et al. 2012; Wang et al. 2012). We did not observe signs of such a process in C. sativa, as the gene density on the $\mathrm{X}$ chromosome is similar to the gene density on the autosomes ( 32 genes / $\mathrm{Mb}$ vs. 33 genes / Mb). It is thus possible that the sex chromosomes are the largest in C. sativa simply because the sex-determining genes happened to evolve on the largest pair of chromosomes.

\section{C. sativa sex chromosome are old}


bioRxiv preprint doi: https://doi org/10.1101/721324; this version posted July 31 2019. The copyright holder for this preprint (which was not certified by peer review) is the author/funder, who has granted bioRxiv a license to display the preprint in perpetuity. It is made $\underline{\text { RESEARCH }}$ available under aCC-BY-NC-ND 4.0 International license.

Age estimates of the $C$. sativa sex chromosome ranges from $\sim 12$ My to $\sim 29$ My old (Table 2).

This is possible given that dioecy probably is ancestral for the whole Cannabaceae family that diversified $\sim 80$ My ago (Zhang et al. 2019). They may be the oldest sex chromosomes in plants for which the age was inferred from sequence data (Ming et al. 2011; Charlesworth 2015; Muyle et al. 2017). For instance, sex chromosomes are $\sim 11$ My old in S. latifolia (Krasovec et al. 2018) and 8-16 My old in two dioecious Rumex species (Crowson et al. 2017).

Further evidence that the $C$. sativa sex chromosomes are older than those of $S$. latifolia and $R$. hastatulus is the fact that the median $\mathrm{Y} / \mathrm{X}$ expression ratio is $\sim 0.5$, much lower than what has been reported for the other species ( $\sim 0.8$ for S. latifolia (Bergero and Charlesworth 2011; Muyle et al. 2012) and $\sim 0.8$ for the old sex-linked genes $R$. hastatulus (Hough et al. 2014)), and that gene loss is about $70 \%$, which is very higher than those species ( $\sim 40 \%$ for S. latifolia (Papadopulos et al. 2015; Muyle et al. 2018) and 30\% in R. hastatulus (Hough et al. 2014)). In $R$. rothschildianus, gene loss amounts $\sim 90 \%$ but the degeneration speed not the age of the system is believed to explain this observation (Crowson et al. 2017)). Thus, the Y chromosome of $C$. sativa seems more strongly degenerated than the Y chromosomes of species with strong heteromorphism.

\section{Implications for the model for sex chromosome evolution in plants}

Most of the plant sex chromosome systems that have been studied so far either have small non-recombining regions and homomorphic sex chromosomes (e.g. Carica papaya, Asparagus officinalis, Diospyros lotus), or have heteromorphic sex chromosomes with the Y being larger than the X (e.g. Silene latifolia, Coccinia grandis). We here found that in a species with (nearly) homomorphic sex chromosomes, the non-recombining region is large, as 
bioRxiv preprint doi: https://doi.org/10.1101/721324; this version posted July 31, 2019. The copyright holder for this preprint (which was not certified by peer review) is the author/funder, who has granted bioRxiv a license to display the preprint in perpetuity. It is made $\underline{\text { RESEARCH }}$ available under aCC-BY-NC-ND 4.0 International license.

it represents $\sim 70 \%(85 / 105 \mathrm{Mb})$ of the $C$. sativa sex chromosomes (as suggested in

(Divashuk et al. 2014) based on cytogenetic data).

A.

(1)

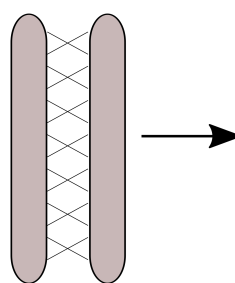

(2)

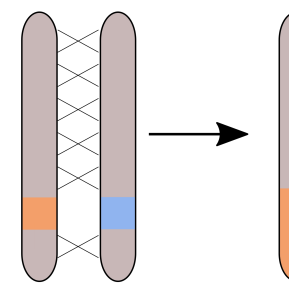

(3)

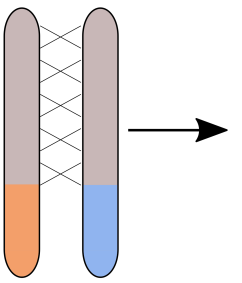

(4)

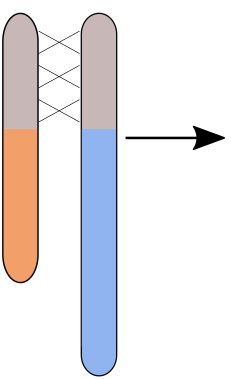

(5)

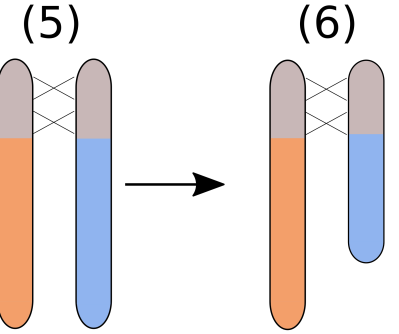

B.

(1)

(2)

(3)

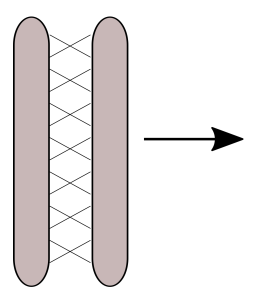

\section{(2)}
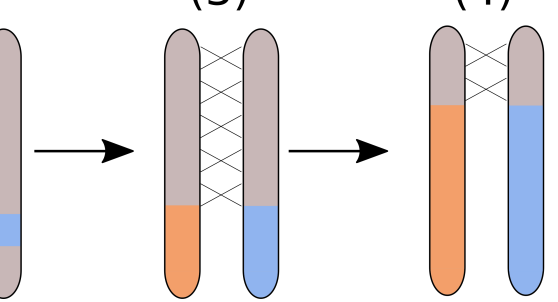

(4)

Autosomal or
pseudo-autosomal regior
Y specific region
X specific region
Recombinaition event

Figure 4: Revisiting the model for the evolution of plant sex chromosomes with C. sativa. A) The current model for the evolution of plant sex chromosomes is as follows: 1) Sex chromosomes originate from autosomes on which sex-determining genes evolve, 2) The region encompassing the sex-determining genes stops recombining, 3) the non-recombining region grows larger due to additional events of recombination suppression, 4) the nonrecombining region of the $\mathrm{Y}$ chromosome accumulates repeats and can become larger than the corresponding region on the $\mathrm{X}$ chromosome, 5-6) the $\mathrm{Y}$ chromosome undergoes large deletions, and ultimately becomes smaller than the X chromosome. Steps 1-4 have been previously documented in plants (e.g. (Charlesworth et al. 2005; Ming et al. 2011; Muyle et al. 2017) for review) while steps 5-6 are very speculative. Our study is supportive of this scenario if we assume that the $C$. sativa $\mathrm{Y}$ chromosome has been larger in the past. B) It is possible however that the accumulation of repeats has been slow in the $\mathrm{Y}$ chromosome of the C. sativa lineage and that $\mathrm{X}$ and $\mathrm{Y}$ chromosomes have always been of similar size (see text). Here step 4 does not imply the elongation of $Y$ chromosome.

In the current scenario for the evolution of the sex chromosomes in plants (Ming et al. 2011;

Charlesworth 2015; Muyle et al. 2017), it is unclear where these XY chromosomes fit.

Indeed, sex chromosome evolution in plants is thought to start with a small non-recombining 
bioRxiv preprint doi: https://doi.org/10.1101/721324: this version posted July 31, 2019. The copyright holder for this preprint (which was not certified by peer review) is the author/funder, who has granted bioRxiv a license to display the preprint in perpetuity. It is made

\section{RESEARCH} available under aCC-BY-NC-ND 4.0 International license.

region on the Y chromosome, which accumulates DNA repeats and tends to grow (Figure 4). In papaya, the $\mathrm{Y}$ non-recombining region is $\sim 8 \mathrm{Mb}$ large while the $\mathrm{X}$ homologous region is $\sim 4$ $\mathrm{Mb}$ (Wang et al. 2012). In some dioecious plants, DNA repeat accumulation in the Y nonrecombining region has been fast and $\mathrm{Y}$ chromosomes that are much larger than the $\mathrm{X}$ have evolved in Silene latifolia (Matsunaga et al. 1994) and Coccinia grandis (Sousa et al. 2013).

Either DNA repeat accumulation on the $\mathrm{Y}$ has been slow in the $C$. sativa lineage, or the $\mathrm{Y}$ used to be larger than it is today and has undergone genomic shrinking, a process that is reminiscent of the evolution of the sex chromosomes in animals (Ming et al. 2011; Bachtrog 2013), where old Y chromosomes can be tiny compared to their X counterpart (Figure 4). Distinct assemblies for the $\mathrm{X}$ and $\mathrm{Y}$ chromosomes in $C$. sativa and also sequencing of other dioecious Cannabaceae species will help testing this idea in the future.

\section{METHODS}

\section{Plant material, RNA extraction, and sequencing}

One male and one female $C$. sativa plants ('Zenista' cultivar) were grown in controlled conditions in greenhouse. A female was crossed with a male plant (controlled pollination). Seeds from this cross were sown to produce the F1. Flower buds were sampled from the parents and 5 offspring of each sex as in (Muyle et al. 2012). Total RNA was isolated from young floral buds using the "RNeasy Plant Mini Kit" (Qiagen) plant isolation kit as recommended by the producer. After isolation of the RNA was placed in tubes RNAstable $\mathbb{R}$ (Sigma). One library per individual was prepared. RNA-sequencing was conducted using the Complete Genomic (CG) technology, which provides 20 millions $\sim 50$ bp single-end reads per 


\section{RESEARCH} available under aCC-BY-NC-ND 4.0 International license.

sample (Liu et al. 2012). Two CG runs were done and we obtained a mean of 48 millions reads per individuals (see Table S1). Read quality was good (phred score $>35$ for all reads) and no trimming was performed.

\section{Mapping, genotyping and SEX-DETector analysis}

The SEX-DETector analysis requires mapping the reads of the individuals onto a reference transcriptome and performing a SNP-calling to genotype all individuals for all expressed genes. We extracted the 30,074 transcripts from the annotation of the 2011 complete genome (van Bakel et al. 2011). The initial mapping analyses were done using BWA, allowing for 5 mismatches per read (version 0.7.15-r1140, bwa aln -n 5 and bwa samse, see (Li and Durbin 2010)) and Bowtie2 (version 2.1.0, bowtie2-build and bowtie2 -x, see (Langmead and Salzberg 2012)). We used Samtools (version 1.3.1, samtools view -t output.fa -F 4 -h and samtools sort -m 2G, see ( $\mathrm{Li}$ et al. 2009)) to convert files from the mapping .bam files into .sam files and to remove unmapped reads.

The genotyping was performed using reads $2 \operatorname{snp}$ (version 2.0.64, reads $2 \mathrm{snp}$-aeb -min 3 -par 0, see (Gayral et al. 2013)), as recommended (Muyle et al. 2016) (i.e. by accounting for allelic expression biases and without filtering for paralogous SNPs). Only SNPs supported by at least three reads were conserved for subsequent analysis (except in Table S2).

We ran SEX-DETector (-system xy/zw/no_sex_chr -seq -detail -detail-sex-linked -L -SEM thr 0.8 , see (Muyle et al. 2016)) on genotyping data of the 12 individuals. SEX-DETector uses a maximum likelihood approach to estimate the parameters of its model, which include several genotyping error parameters. The posterior probability of being autosomal (P_A), XY $\left(\mathrm{P} \_\mathrm{XY}\right)$ or $\mathrm{X}$-hemizygous $\left(\mathrm{P} \_\mathrm{Xh}\right)$ is then computed for each SNP and then computed for each transcript (combining the posterior probabilities of all SNPs, see (Muyle et al. 2016)). A 


\section{RESEARCH} available under aCC-BY-NC-ND 4.0 International license.

transcript was inferred as sex-linked if its posterior probability of being either XY or Xhemizygous was $\geq 0.8$ (i.e. $\mathrm{P}_{-} \mathrm{XY}+\mathrm{P}_{-} \mathrm{Xh} \geq 0.8$ ) and if at least one sex-linked SNP had no genotyping error; autosomal segregation was inferred similarly $\left(\mathrm{P}_{-} \mathrm{A} \geq 0.8\right.$ and at least one autosomal SNP without genotyping error; see (Muyle et al. 2016)). The remaining transcripts were considered undetermined and were not used for further analysis. Among the sex-linked transcripts, those with an expressed $\mathrm{Y}$-allele were considered XY, the others $\mathrm{X}$-hemizygous.

SEX-DETector runs on the first mapping with BWA and Bowtie2 yielded high Y genotyping error (YGE) parameter values, which could be the result of mapping errors of Y-linked reads (Muyle et al. 2016). The reference transcriptome used for mapping was derived from the genome of a female plant (van Bakel et al. 2011), which may result in a mapping bias against the Y-linked reads. To solve this problem, we used GSNAP (version 2017-11-15, gsnap -m 5, see (Wu and Nacu 2010)), which can be used to map RNA-seq reads onto a divergent reference. GSNAP was thus used in a SNP-informed mode that adjusts read alignment onto a reference taking into account a user-provided list of SNPs that are not considered as mismatches. For this procedure, we first mapped reads with BWA and collected all the SNPs present in SEX-DETector output, which were provided to GSNAP. We ran four iterations of GSNAP. For each iteration, SEX-DETector detected new sex-linked SNPs, which were added to the list of SNPs provided to GSNAP. As expected, the Y genotyping error parameter value decreased from 0.84 with BWA to 0.07 with 4th GSNAP iteration (Table S2), and the mapping rate from $82.57 \%$ to $87 \%$ (Table S1).

\section{Circular representations of location of sex-linked genes in the $C$. sativa genome}

To map the sex-linked genes onto the $C$. sativa genome, we used blast to find the best hit of each C. sativa transcript in the 2011 transcriptome on a recent (unannotated) reference 
bioRxiv preprint doi: https://doi org/10.1101/721324; this version posted July 31, 2019. The copyright holder for this preprint (which was not certified by peer review) is the author/funder, who has granted bioRxiv a license to display the preprint in perpetuity. It is made

\section{RESEARCH} available under aCC-BY-NC-ND 4.0 International license.

genome (blastn -max_target_seqs 1 -max_hsps 1). For this mapping, we used the C. sativa reference genome with the best assembly statistics ( 1 ize $=875 \mathrm{Mb}, 10$ pseudomolecules, 220 scaffolds, N50 = $91 \mathrm{Mb}$, see https://www.ncbi.nlm.nih.gov/genome/genomes/11681 and (Grassa et al. 2018)). We then used Circos (version 0.69-6) for visualizing the location of sexlinked genes. The total gene number per window along the $C$. sativa genome was obtained by dividing the number of mapped transcripts by window size. Bedtools makewindows (version v2.26.0) was used for the separation of the genome in windows of $2 \mathrm{Mb}$ and bedtools intersect (version v2.26.0, -c option) for computing the gene number per window.

\section{Analysis of the sex-linked genes}

Y gene loss. To estimate the rate of gene loss in the $\mathrm{Y}$ chromosome, we compared the number of $\mathrm{X} / \mathrm{Y}$ gene pairs and the number of $\mathrm{X}$-hemizygous genes as in (Bergero and Charlesworth 2011). Identifying $X / Y$ gene pairs relies on fixed $X / Y$ differences while identifying $X-$ hemizygous genes relies on X-polymorphism only, which makes detection of X-hemizygous genes less likely (see (Bergero and Charlesworth 2011; Muyle et al. 2016)). Y gene loss proportion estimate was thus corrected for this bias as follows:

$\mathrm{Y}$ gene loss $=\mathrm{X}$-hemizygous genes number $/(\mathrm{X}$-hemizygous genes number $+\mathrm{XY}$ gene pairs with $\mathrm{X}$ polymorphism number)

Values of synonymous divergence (dS) and age of the XY system. The $\mathrm{X}$ and $\mathrm{Y}$ open reading frames sequences were aligned using the translated reference transcripts to get reading-frame informed alignments. X-Y dS values were obtained using codeml (PAML version 4.9, see (Yang 2007)) in pairwise mode. To estimate the age of the $C$. sativa XY system, we considered maximum X-Y dS values and used two different molecular clocks for plants: $1.5 \mathrm{x}$ 
bioRxiv preprint doi: https://doi.org/101101/721324: this version posted July 31, 2019. The copyright holder for this preprint (which was not certified by peer review) is the author/funder, who has granted bioRxiv a license to display the preprint in perpetuity. It is made

\section{RESEARCH} available under aCC-BY-NC-ND 4.0 International license.

$10^{-8}$ substitutions / site / year (Koch et al. 2000) and $7 \times 10^{-9}$ mutations / site / generation (Ossowski et al. 2010). We obtained age of the XY system as follows:

age (in years) $=\mathrm{dS} \max /$ rate, using (Koch et al. 2000) molecular clock

age (in number of generations) $=\mathrm{dS} \max / 2 \mu$, using (Ossowski et al. 2010) molecular clock; the age in million years was obtained assuming 1 generation per year in natural populations of C. sativa.

Allele-specific expression analysis. We used allele-specific expression estimates at $\mathrm{X} / \mathrm{Y}$ gene pairs provided by SEX-DETector (Muyle et al. 2016) for the estimation of Y/X expression ratio and patterns of dosage compensation (see Figure 3B-C). These estimates relied on counting reads spanning X/Y SNPs only and were normalized using the total read number in a library for each individual. These estimates were further normalized by the median autosomal expression for each individual.

\section{Identifying sex-biased genes}

As the differential gene expression analysis methods currently available varied in performance (Schurch et al. 2016; Costa-Silva et al. 2017), we chose to combine several methods. Analysis contrasting the gene expression level between our 12 male and female individuals were thus performed using three R packages (i) DEseq2 version 1.10.1 (Love et al. 2014), (ii) EdgeR version 3.26.9 (Robinson et al. 2010) both relying on negative binomial distribution of read count modelling and (iii) limma-voom version 3.26.9 (Ritchie et al. 2015) based on log-normal distribution modelling to take into account the sampling variance of small read counts. Very low expressed genes were discarded from the analysis, keeping only genes covered by at least 10 reads in a minimum of two replicates. Using a FDR adjusted p- 


\section{RESEARCH} available under aCC-BY-NC-ND 4.0 International license.

value cut-off of 0.001 , we retained as sex-biased the genes that had significant differences in expression between males and females in at least two of the three methods (Figure S3).

\section{Statistics}

All statistical tests and figures were done using R (version 3.2.3, (Team 2016)).

\section{DATA ACCESS}

Data are available in the NCBI database under the accession numbers SAMN12097880 to SAMN12097891

\section{ACKNOWLEDGMENTS}

We thank the BGI for free sequencing thanks to their call for RNA-seq for medicinal plants. We thank Aline Muyle for advice with SEX-DETector and discussions. We thank Dr Tatyana Sukhorada, P.P. Lukyanenko Krasnodar Research and Development Institute of Agriculture for providing seeds of $C$. sativa cultivar 'Zenitsa'. This project was supported through ANR grant ANR-14-CE19-0021-01 to G.A.B.M.

Author Contributions

Conceptualization of the study: GABM, GK; Methodology: GABM, GK; Software: DP, BR, HB; Formal analysis: DP; Investigation: DP, OR, BR, HB, HH, JK, GK, GABM; Resources: 
bioRxiv preprint doi: https://doi org/101101/721324; this version posted July 31,2019. The copyright holder for this preprint (which was

not certified by peer review) is the author/funder, who has granted bioRxiv a license to display the preprint in perpetuity. It is made

$\underline{\text { RESEARCH }}$ available under aCC-BY-NC-ND 4.0 International license.

OR, CF, GK; Data curation: CF; Writing - original draft: GABM, DP, JK; Writing - review and editing: all authors; Visualization: DP; Supervision: GABM, JK, GK; Project administration: GABM; Funding acquisition: GABM, GK.

DISCLOSURE DECLARATION (including any conflicts of interest)

The authors declare no conflicts of interest

\section{REFERENCES}

Alexander SP. 2016. Therapeutic potential of cannabis-related drugs. Progress in neuropsychopharmacology \& biological psychiatry 64: 157-166.

Andre CM, Hausman JF, Guerriero G. 2016. Cannabis sativa: The Plant of the Thousand and One Molecules. Front Plant Sci 7: 19.

Bachtrog D. 2013. Y-chromosome evolution: emerging insights into processes of Ychromosome degeneration. Nat Rev Genet 14(2): 113-124.

Barrett SC, Hough J. 2013. Sexual dimorphism in flowering plants. J Exp Bot 64(1): 67-82.

Bergero R, Charlesworth D. 2011. Preservation of the Y transcriptome in a 10-million-yearold plant sex chromosome system. Curr Biol 21(17): 1470-1474.

Charlesworth D. 2015. Plant contributions to our understanding of sex chromosome evolution. New Phytol 208(1): 52-65.

Charlesworth D, Charlesworth B, Marais G. 2005. Steps in the evolution of heteromorphic sex chromosomes. Heredity 95(2): 118-128. 
bioRxiv preprint doi: https://doi org/101101/721324; this version posted July 31,2019. The copyright holder for this preprint (which was

not certified by peer review) is the author/funder, who has granted bioRxiv a license to display the preprint in perpetuity. It is made

$\underline{\text { RESEARCH }}$ available under aCC-BY-NC-ND 4.0 International license.

Costa-Silva J, Domingues D, Lopes FM. 2017. RNA-Seq differential expression analysis: An extended review and a software tool. PLoS One 12(12): e0190152.

Crowson D, Barrett SCH, Wright SI. 2017. Purifying and Positive Selection Influence Patterns of Gene Loss and Gene Expression in the Evolution of a Plant Sex Chromosome System. Mol Biol Evol 34(5): 1140-1154.

Divashuk MG, Alexandrov OS, Razumova OV, Kirov IV, Karlov GI. 2014. Molecular cytogenetic characterization of the dioecious Cannabis sativa with an XY chromosome sex determination system. PLoS One 9(1): e85118.

Gayral P, Melo-Ferreira J, Glemin S, Bierne N, Carneiro M, Nabholz B, Lourenco JM, Alves PC, Ballenghien M, Faivre $\mathrm{N}$ et al. 2013. Reference-free population genomics from next-generation transcriptome data and the vertebrate-invertebrate gap. PLoS Genet 9(4): e1003457.

Grassa CJ, Wenger JP, Dabney C, Poplawski SG, Motley ST, Michael TP, Schwartz C, Weiblen GD. 2018. A complete Cannabis chromosome assembly and adaptive admixture for elevated cannabidiol (CBD) content. BioRxiv: 458083.

Gschwend AR, Yu Q, Tong EJ, Zeng F, Han J, VanBuren R, Aryal R, Charlesworth D, Moore PH, Paterson AH et al. 2012. Rapid divergence and expansion of the $\mathrm{X}$ chromosome in papaya. Proc Natl Acad Sci U S A 109(34): 13716-13721.

Hobza R, Cegan R, Jesionek W, Kejnovsky E, Vyskot B, Kubat Z. 2017. Impact of Repetitive Elements on the Y Chromosome Formation in Plants. Genes 8(11).

Hough J, Hollister JD, Wang W, Barrett SC, Wright SI. 2014. Genetic degeneration of old and young Y chromosomes in the flowering plant Rumex hastatulus. Proc Natl Acad Sci USA. 
bioRxiv preprint doi: https://doi org/101101/721324; this version posted July 31,2019. The copyright holder for this preprint (which was

not certified by peer review) is the author/funder, who has granted bioRxiv a license to display the preprint in perpetuity. It is made

$\underline{\text { RESEARCH }}$ available under aCC-BY-NC-ND 4.0 International license.

Koch M, Haubold B, Mitchell-Olds T. 2000. Comparative evolutionary analysis of chalcone synthase and alcohol dehydrogenase loci in Arabidopsis, Arabis and related genera (Brassicaceae). Molecular Biology and Evolution 17: 1483-1498.

Krasovec M, Chester M, Ridout K, Filatov DA. 2018. The Mutation Rate and the Age of the Sex Chromosomes in Silene latifolia. Curr Biol 28(11): 1832-1838.e1834.

Langmead B, Salzberg SL. 2012. Fast gapped-read alignment with Bowtie 2. Nat Methods 9(4): $357-359$.

Laverty KU, Stout JM, Sullivan MJ, Shah H, Gill N, Holbrook L, Deikus G, Sebra R, Hughes TR, Page JE et al. 2019. A physical and genetic map of Cannabis sativa identifies extensive rearrangements at the THC/CBD acid synthase loci. Genome Res 29(1): 146-156.

Li H, Durbin R. 2010. Fast and accurate long-read alignment with Burrows-Wheeler transform. Bioinformatics 26(5): 589-595.

Li H, Handsaker B, Wysoker A, Fennell T, Ruan J, Homer N, Marth G, Abecasis G, Durbin R. 2009. The Sequence Alignment/Map format and SAMtools. Bioinformatics 25(16): 2078-2079.

Liu L, Li Y, Li S, Hu N, He Y, Pong R, Lin D, Lu L, Law M. 2012. Comparison of nextgeneration sequencing systems. BioMed research international 2012.

Love MI, Huber W, Anders S. 2014. Moderated estimation of fold change and dispersion for RNA-seq data with DESeq2. Genome Biol 15(12): 550.

Matsunaga S, Hizume M, Kawano S, Kuroiwa T. 1994. Cytological analyses in Melandrium album: genome size, chromosome size and fluorescence in situ hybridization. 


\section{Cytologia 59: 135-141.}

McVey E. 2017. U.S. marijuana industry’s economic impact to approach \$70B by 2021. In Marijuana Business Daily.

Ming R, Bendahmane A, Renner SS. 2011. Sex chromosomes in land plants. Annu Rev Plant Biol 62: 485-514.

Muyle A, Kafer J, Zemp N, Mousset S, Picard F, Marais GA. 2016. SEX-DETector: A Probabilistic Approach to Study Sex Chromosomes in Non-Model Organisms. Genome Biol Evol 8(8): 2530-2543.

Muyle A, Shearn R, Marais GA. 2017. The Evolution of Sex Chromosomes and Dosage Compensation in Plants. Genome Biol Evol 9(3): 627-645.

Muyle A, Zemp N, Deschamps C, Mousset S, Widmer A, Marais GA. 2012. Rapid de novo evolution of X chromosome dosage compensation in Silene latifolia, a plant with young sex chromosomes. PLoS Biol 10(4): e1001308.

Muyle A, Zemp N, Fruchard C, Cegan R, Vrana J, Deschamps C, Tavares R, Hobza R, Picard F, Widmer A et al. 2018. Genomic imprinting mediates dosage compensation in a young plant XY system. Nature plants 4(9): 677-680.

Offord C. 2018. UK to Legalize Medicinal Cannabis. In The Scientist.

Ossowski S, K Schneeberger JIL-L, Norman Warthmann, Richard M. Clark, Ruth G. Shaw, Weigel D, Lynch M. 2010. The rate and molecular spectrum of spontaneous mutations in Arabidopsis thaliana. Science 327: 92-94.

Papadopulos AS, Chester M, Ridout K, Filatov DA. 2015. Rapid Y degeneration and dosage compensation in plant sex chromosomes. Proc Natl Acad Sci U S A 112(42): 13021- 


\section{RESEARCH}

13026.

Renner SS. 2014. The relative and absolute frequencies of angiosperm sexual systems: dioecy, monoecy, gynodioecy, and an updated online database. Am J Bot 101(10): 1588-1596.

Ritchie ME, Phipson B, Wu D, Hu Y, Law CW, Shi W, Smyth GK. 2015. limma powers differential expression analyses for RNA-sequencing and microarray studies. Nucleic Acids Res 43(7): e47.

Robinson MD, McCarthy DJ, Smyth GK. 2010. edgeR: a Bioconductor package for differential expression analysis of digital gene expression data. Bioinformatics 26(1): 139-140.

Salentijn EM, Petit J, Trindade LM. 2019. The Complex Interactions Between Flowering Behavior and Fiber Quality in Hemp. Frontiers in plant science $\mathbf{1 0 .}$

Schultes RE, Klein WM, Plowman T, Lockwood TE. 1974. Cannabis: an example of taxonomic neglect. Botanical Museum Leaflets, Harvard University 23(9): 337-367.

Schurch NJ, Schofield P, Gierlinski M, Cole C, Sherstnev A, Singh V, Wrobel N, Gharbi K, Simpson GG, Owen-Hughes T et al. 2016. How many biological replicates are needed in an RNA-seq experiment and which differential expression tool should you use? Rna 22(6): 839-851.

Small E. 2015. Evolution and classification of Cannabis sativa (marijuana, hemp) in relation to human utilization. The botanical review 81(3): 189-294.

Sousa A, Bellot S, Fuchs J, Houben A, Renner SS. 2016. Analysis of transposable elements and organellar DNA in male and female genomes of a species with a huge $\mathrm{Y}$ 


\section{RESEARCH} available under aCC-BY-NC-ND 4.0 International license.

chromosome reveals distinct Y centromeres. Plant J 88(3): 387-396.

Sousa A, Fuchs J, Renner SS. 2013. Molecular Cytogenetics (FISH, GISH) of Coccinia grandis : A ca. 3 myr-Old Species of Cucurbitaceae with the Largest Y/Autosome Divergence in Flowering Plants. Cytogenet Genome Res 139(2): 107-118.

Team RC. 2016. R: A language and environment for statistical computing. R Foundation for Statistical Computing, Vienna, Austria. 2015. URL h ttp. www R-project org.

Techen N, Chandra S, Lata H, Elsohly MA, Khan IA. 2010. Genetic identification of female Cannabis sativa plants at early developmental stage. Planta medica 76(16): 19381939.

van Bakel H, Stout JM, Cote AG, Tallon CM, Sharpe AG, Hughes TR, Page JE. 2011. The draft genome and transcriptome of Cannabis sativa. Genome Biol 12(10): R102.

Wang J, Na JK, Yu Q, Gschwend AR, Han J, Zeng F, Aryal R, VanBuren R, Murray JE, Zhang W et al. 2012. Sequencing papaya X and Yh chromosomes reveals molecular basis of incipient sex chromosome evolution. Proc Natl Acad Sci U S A 109(34): $13710-13715$.

Wu TD, Nacu S. 2010. Fast and SNP-tolerant detection of complex variants and splicing in short reads. Bioinformatics 26(7): 873-881.

Yang Z. 2007. PAML 4: Phylogenetic Analysis by Maximum Likelihood. Molecular Biology and Evolution 24(8): 1586-1591.

Yeager A. 2018. Canada Could Come to the Fore in Cannabis Research. In The Scientist.

Zhang Q, Onstein RE, Little SA, Sauquet H. 2019. Estimating divergence times and ancestral breeding systems in Ficus and Moraceae. Ann Bot 123(1): 191-204. 